Article

\title{
Social Representations about Cultural Tourism in the Time of COVID-19: A Case Study of Langhe, Monferrato and Roero (Italy)
}

\author{
Giovanna Rech *(D) and Lorenzo Migliorati
}

check for updates

Citation: Rech, G.; Migliorati, L. Social Representations about Cultural Tourism in the Time of COVID-19: A Case Study of Langhe, Monferrato and Roero (Italy). Sustainability 2021, 13, 6301. https://doi.org/10.3390/ su13116301

Academic Editor: Bart Neuts

Received: 30 April 2021

Accepted: 29 May 2021

Published: 2 June 2021

Publisher's Note: MDPI stays neutral with regard to jurisdictional claims in published maps and institutional affiliations.

Copyright: (c) 2021 by the authors. Licensee MDPI, Basel, Switzerland. This article is an open access article distributed under the terms and conditions of the Creative Commons Attribution (CC BY) license (https:/ / creativecommons.org/licenses/by/ $4.0 /)$.
Department of Human Sciences, University of Verona, 37129 Verona, Italy; lorenzo.migliorati@univr.it

* Correspondence: giovanna.rech@univr.it

\begin{abstract}
Cultural tourism is recognised as one of the broader sectors of the tourism industry, embracing an extensive range of tourist interests. Italy is a remarkable tourist destination due to its cultural appeal in tangible and intangible heritage as well as its cultural resources connected to food and gastronomy, and it is of special interest since the COVID-19 pandemic was declared in March 2020. This study sought to analyse the perceptions of diverse significant actors regarding culture and tourism during the COVID-19 pandemic in Langhe, Monferrato and Roero, an area of southern Piedmont in north-western Italy. As part of a larger collaborative international project addressing the coronavirus situation, the research examined residents, tourists and tourism-related professionals to investigate their perceptions of culture and tourism. Data were collected through a survey employing three distinct questionnaires for the three target groups of residents, tourists and entrepreneurs and cultural bodies. The data analysis reveals that residents embraced a static representation of the local cultural tourism's appeal and heritage, while tourists were motivated mainly by gastronomic and wine experiences. The perception of the coronavirus among the three groups of interviewees reflects a general reduction in almost all cultural activities and travel possibilities.
\end{abstract}

Keywords: cultural tourism; social representations; cultural heritage; COVID-19; Italy

\section{Introduction}

Since Italy is a travel destination, culture and tourism are inextricably connected. Some hyperbolic statements affirm that Italy has 60,75 or $80 \%$ of the world's cultural heritage: these percentages seem more of a claim than judgements of fact. In writing about arts and cultural heritage, some journalists have sought to discuss them in light of the UNESCO World Heritage List or cultural participation statistics, but they remain substantially unfounded [1-3]. The Best Countries ranking of the US News \& World Report has put Italy as the best country for cultural influence and in second place for heritage [4]. This and similar reports suggest the most common representations about Italy and its heritage from the perspective of those outside Italy.

The matter is more complex for those inside the country's borders because of great regional differences and an ambiguous long-lasting relationship between culture and tourism, from both an institutional and policy-making perspective. The recognition of the key role of tourism has changed over time, but the health emergency due to the coronavirus, which began in early 2020, unfortunately, gave it great media coverage. The pandemic contributed to a larger resonance to the "tourism dependence" of the Italian economy, employment rates and its international reputation [5].

The case study area of Langhe, Monferrato and Roero, an area of southern Piedmont in north-west Italy, is strongly characterised by important and well-known vineyards, by producing fine wines and the assortment of very particular local products such as the white truffle of Alba. The beauty and characteristics of this hilly landscape, together with authentic winegrowing and winemaking traditions, led to the inscription of part of this 
area on the UNESCO World Heritage List in 2014 as The Vineyard Landscape of Piedmont: Langhe-Roero and Monferrato. As serial property, its outstanding value is recognised in harmony between nature and men's work, architecture and local history [6]. These same considerations concern local attractions for tourism, characterised by a rural environment and its related products [7-9]). The area is also represented through the special form of intangible heritage in literature: between the late nineteenth and twentieth century, this area gave rise to many famous intellectuals who lived, wrote, and in some cases, even fought the War of Liberation in this part of Italy. They have inhabited the cultural imaginary of many generations of Italians: from classic to realist writers, poets and men of letters, also internationally well known for their works of regional and local rooting. Among the best known, we mention Vittorio Alfieri, Giovanni Arpino, Luigi Einaudi, Beppe Fenoglio, Davide Lajolo, Augusto Monti and Cesare Pavese [10]. Rurality, cultural tangible and intangible heritage, and a creative milieu coexist in this case study. Different aspects of the landscape beauty, specific typical products, built as well as intangible historical resources differently contribute to shaping this destination and attract tourists from Italy and from abroad.

Since the second half of the 1980s, the role of local communities in tourist destination management and success has become a growing concern in tourism planning [11], and it includes critical elements with respect to governance strategies [12]. Residents' perceptions of tourism have constituted a well-developed field of research in tourism studies since the 1990 s $[13,14]$. In the USA earlier in this century, researchers analysed diverse aspects of tourism's effects on the community in Arizona [15] and the cultural benefits of residence along a historic scenic byway in Colorado [16]. More recently, residents' perceptions were investigated in emerging countries in the context of tourism's sociocultural impacts [17].

This article sought to analyse the perceptions of various actors regarding culture and tourism during the COVID-19 pandemic in Langhe, Monferrato and Roero. Within a larger, internationally led project, it considers the representations of the local communities (residents and tourism-related professionals) and tourists by investigating their perceptions of culture and tourism. This article describes how the case study area evaluates and enhances its cultural resources in light of tourism activities.

The case study research questions revolved around the insiders' understanding of culture and tourism in the case study area. The fieldwork was conducted in early autumn 2020, when the coronavirus crisis seemed to be loosening its grip on Italian domestic travel, a period marked by the apparent return of tourists after months of closures and social distancing. The impacts of the COVID-19 situation on the ongoing connection between culture and tourism in this territory are examined from the perspective of the interviewees and in light of the local stakeholders' responses.

\section{Cultural Tourism: Definitions and Problems from an Italian Perspective}

\subsection{An Overview of Cultural Tourism}

Cultural tourism has been recognised as one of the largest and fastest-growing tourism sectors, at least until early 2020 when the pandemic was declared. Tourism is a social phenomenon that puts the economy, environment, culture, and politics into a complex and interrelated system. Over time, scholars and policy makers have developed actions of various nature and scope regarding tourism, its organisation, management, and planning. Local stakeholders, namely host communities and local entrepreneurs, have different concerns regarding the tourism industry because it represents both a source of wealth and a potential cause of cultural change. Nowadays, the most shared perspective, in which the development of such a complex social and economic activity can be thought, is the paradigm of sustainability with its contradictions and rhetoric [18-21].

It is very difficult to define cultural tourism because the notion of culture is always directly related to the perspective of time and space. Reference is generally made to visiting the cultural resources of a place, region or country. To preliminarily define it, cultural tourism seems to be one of the earliest forms of mobility for expressive and communicative 
purposes, and not just for instrumental ones. Interest in the cultures, habits, customs, and artefacts of others, together with a general desire to push the boundaries of knowledge, are traits coexisting in humanity itself [22].

Cultural tourism manages to combine not only different resources for tourists' attractions but also different activities to entertain them [23]. Therefore, tangible and intangible heritage, landscape, traditional knowledge and crafts are all motivations for tourists, while host communities work on their own legacies and practices to present themselves on the "glocal" tourist market [24].

Examining its historical development, the emergence of a cultural tourism emphasises different values over time. Representations of the high culture, arts, and history characterised Italian attractiveness in the early times of travels and tourism. More recently, the interest for the natural and the authentic can be related both to the incessant urbanisation, which involves all Western countries, and a sort of progressive sophistication that leads from the proximity to nature and pre-industrial culture to the actual post-industrial societies [25].

In the current European societies, the urban and rural contexts are equally considered cultural tourism destinations, especially since attention to experiences and the active role of tourists has progressively differentiated the tourism supply and demand process [26]. Rural environment through landscape attractiveness $[27,28]$ and its related products meet the postmodern tourist's search for food and gastronomy [29,30].

Therefore, the sociological understanding of cultural tourism is complex, so much so that it can be categorised on the basis of both the activities undertaken and the motivation that drives the tourist to carry them out. As Du Cros and McKercher and [31] underline, when tourism is analysed from multiple points of view, a sort of circularity emerges. If a technical definition of cultural tourism takes into account all the movements of people towards cultural attractions, a conceptual definition instead privileges the cognitive traits of this shift, highlighting the travellers' intention to collect new information and experiences to satisfy their own cultural needs [32].

Culture is promoted to attract travellers to a certain location or to offer particular experiences: impacts of tourism on culture and cultural reproduction are widely discussed, especially when specific identity traits enter the consumer circuit and cause various impacts on the cultural characteristics of the host communities [33]. Today, cultural tourism focuses on the attractions, activities and experiences that become the main motivating factors for travel, even if their practices receive growing and crucial attention [34]. Nonetheless, classifying the forms of cultural tourism is always a partial exercise: it can take into account the cultural products of the present or the past offered to or enjoyed by tourists. For this reason, it can relate to the past with its traditions and its objects: the interest in history is expanding enormously, especially with its transformation into heritage. Yet as Holtorf argues [35], looking at heritage futures, it is less important to know what cultural heritage is than what it does.

Heritage seems omnipresent today and operates as a constant process that involves cultural resources and operates massively through social and institutional arrangements at different international, national and local levels [36]. Among these, non-governmental organisations focusing on the peaceful expansion of knowledge and education, such as UNESCO, have a very particular role in the taxonomy of cultural tourism and the activities that are undertaken locally. The participatory processes of an inscription on the World Heritage List are an aspect of cultural tourism with an ever-wider impact [37], including in Italy [38].

It is precisely because of the breadth and temporal rootedness of the relationship between society and culture, on the one hand, and tourism, on the other, that the great "container" of cultural tourism could be attributed to entertainment and holidays, the experience of food and wine, and visiting cultural heritage sites and buildings. Likewise, the enjoyment of the geographical features, the environment, and the ways of life of the 
inhabitants of a certain region, as well as its historical sites, significant attractions, and its ritual customs, are a cultural experience.

\subsection{Defining Cultural Tourism in Italy}

Italy is a privileged destination for cultural tourism in the world. It still benefits from a sort of historical and touristic stratification. Some scholars trace the matrix of today's cultural tourism to the practice of the Grand Tour historically developed between the sixteenth and eighteenth centuries [39]. Through the rediscovery of ancient Roman civilization, the two centuries of the Grand Tour certainly represented one of the first historical moments in which it was possible to experience a peaceful cosmopolitanism. However, it was reserved for a small group of travellers, mainly aristocrats coming from the Northern regions of Europe. Within the Grand Tour, the Italian peninsula and its culture is recognised as having a central role in inspiring the changes in the European social space through the spread of Renaissance ideas [40].

Protecting and safeguarding cultural heritage is an opportunity to motivate today's tourists to visit Italian heritage, and it arises in the wake of the past, such as in the past the Grand Tourists came to the Italian peninsula. Historical heritage and the development of a heritage consciousness in the Italian pre-Unitarian states were realised in a chronological parallel of the Grand Tour practices. According to art historians, the Italian peninsula was at the forefront in the protection of its historical and artistic heritage in the pre-Unitarian and pre-republican periods [41].

In their contribution to pioneering work in the study of cultural tourism, van der Borg and Costa [42] considered cultural heritage connected to the listed and protected conservation areas officially recognised by the Italian Ministry of Culture and Tourism. A definition of cultural tourism for Italy, starting from the official statistics compiled by the Italian Institute of Statistics [43], takes into account its restriction to the sphere of cultural heritage, especially historical and artistic sites and monuments. Nevertheless, as pointed out in the periodic report on Italian tourism (Rapporto sul turismo italiano), it is important to shift from the "Site and monument approach to the experience approach" in the field of tourism and cultural consumption [44]. Nowadays, the role of tourist attractions is granted to Italian cultural resources as a whole: in other words, the visitor and the tourist are consumers of Italian culture [45], in its broadest sense. Culture and tourism have a virtuous relationship because they may cover a spectrum of Italian cultural activities that extend from museums to cities and places of art in a growing combination of creative industries and the growth of tourism that also considers the landscape as an element of great interest [46].

\subsection{Research Questions for the Italian Case Study}

In the multidisciplinary field of tourism studies, tourism planning is that set of analyses and practices that aim to develop tourism in a controlled and integrated manner in order to maximise its positive impacts and minimise the negative ones (Edgell et al., 2013).

Concluding his historical overview on tourism and social sciences, Holden (2005) argues: "destinations that we view as desirable to visit are highly influenced by cultural perceptions" (p. 37). Those are both produced in the destination area and in the tourists' homes. This is why the local community's representations of cultural resources for tourism is an interesting issue to question not only the renowned tourist attractions but also residents' most meaningful heritage. Rural tourism is considered a strong lever for the case study area, above all in its rooting into the multiple dimensions of intangible heritage and resources for the tourist attraction $[9,47]$.

The coronavirus pandemic has completely overturned all the terms of tourism space interrelations planning and objectives; actors and governance; stakes, motivations and behaviour, and the tourist consumption of individuals and groups. However, the situation in which we are still immersed (as of writing this article in February 2021) also has the burden of making us reflect deeply and for a long time on many aspects that affect the 
most recent past, the present, and above all, the future of tourism not only at the regional and national level but worldwide. If in other aspects of social life, the consequences of the pandemic are still developing, in tourist mobility, they have had immediate and disruptive visibility, forcing us to think in a completely changed context in terms of economic system, social distancing and ecological concerns [48-52].

\section{Materials and Methods}

The research design partly depended on the international project's directions and was partly adjusted to the local research question focusing on the local perception of cultural tourism. A quantitative survey was carried out on three target groups: residents, tourists, and entrepreneurs and cultural bodies. A certain freedom in research design allowed to adapt the data collection methods and numerous samples. The reference universe was not previously circumscribed, so the samples were modulated according to each specific target. This article has selected the questionnaire items and questions concerning the social representation of cultural tourism in the case study area in the three targets, connecting them to their perception of the coronavirus situation.

\subsection{Residents Sampling}

For residents, the territorial integration area of Alba was selected, as defined by the 2011 Regional Territorial Plan of Piedmont [53] (Figure 1). The area includes 75 municipalities, among which the 44 with at least 500 inhabitants were selected.

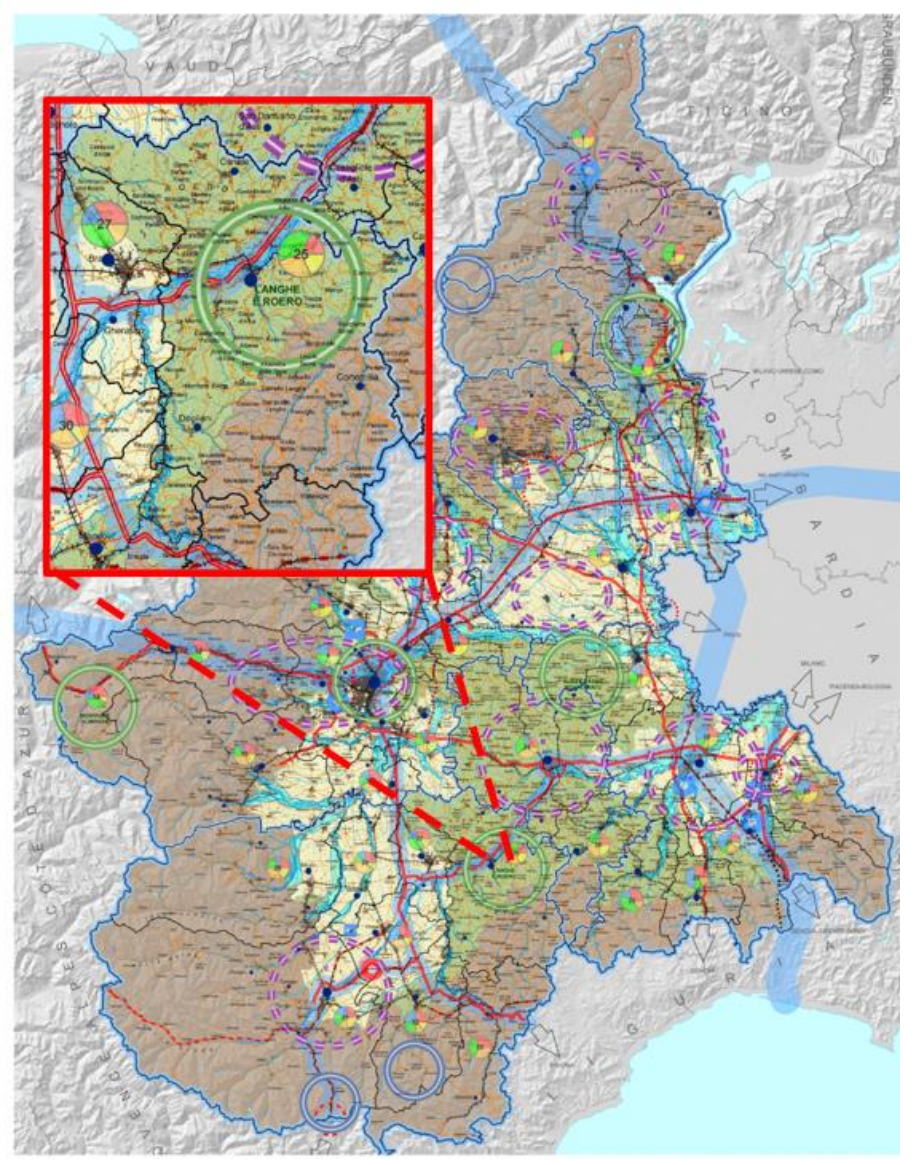

Figure 1. The territorial integration area in the Regional Territorial Plan of Piedmont. Source: https:/ / www.regione.piemonte.it/web/temi/ambiente-territorio/territorio/pianoterritoriale-regionale-ptr (accessed on 7 July 2020). 
The reference universe was thus made up of about 95,000 residents, according to the official Italian demographic statistics [54]. We proceeded to construct a sample of 400 adults stratified by gender and age (42.5\% men and 57.5\% women), to whom we administered the questionnaire relating to the group of residents, using CATI (Computer Assisted Telephone Interview) and CAWI (Computer Assisted Web Interview). The research was carried out in October 2020.

\subsection{Tourists Sampling}

For tourists, mixed data collection was chosen: face-to-face interview and eventually through CAWI (after they personally provided a link). The convenience sampling method was chosen, trying to diversify it both for gender (reaching about half males and females) and age. Finally, the result is a self-selected convenience sample, as the willingness to answer the questionnaire was quite low.

The International White Truffle Fair inauguration weekend in Alba (9-11 October 2020) and the weekends following the in-presence fair were judged as the best time to meet visitors face-to-face (both excursionists and tourists [55]. The research team planned to approach every tourist in three spots (see below), queuing for the entrance to the Tourism Office, the International White Truffle Fair stands and the Grinzane Cavour Castle, until a targeted number of between 12 and 20 respondents was reached by each of the three researchers. Because of new national sanitary restrictions for containing the coronavirus, just one round of data collection was carried out, collecting 46 questionnaires

\subsection{Entrepreneurs and Cultural Bodies Sampling}

For entrepreneurs and cultural bodies, the questionnaire was structured for CAWI collection, starting from the entire directory of activities in the Western area of the Langhe Monferrato and Roero local destination management organisation. The final sample (data collection October-December 2020) is composed of 215 anonymised questionnaires. The result is a non-probabilistic self-selected convenience sample (Figure 2).

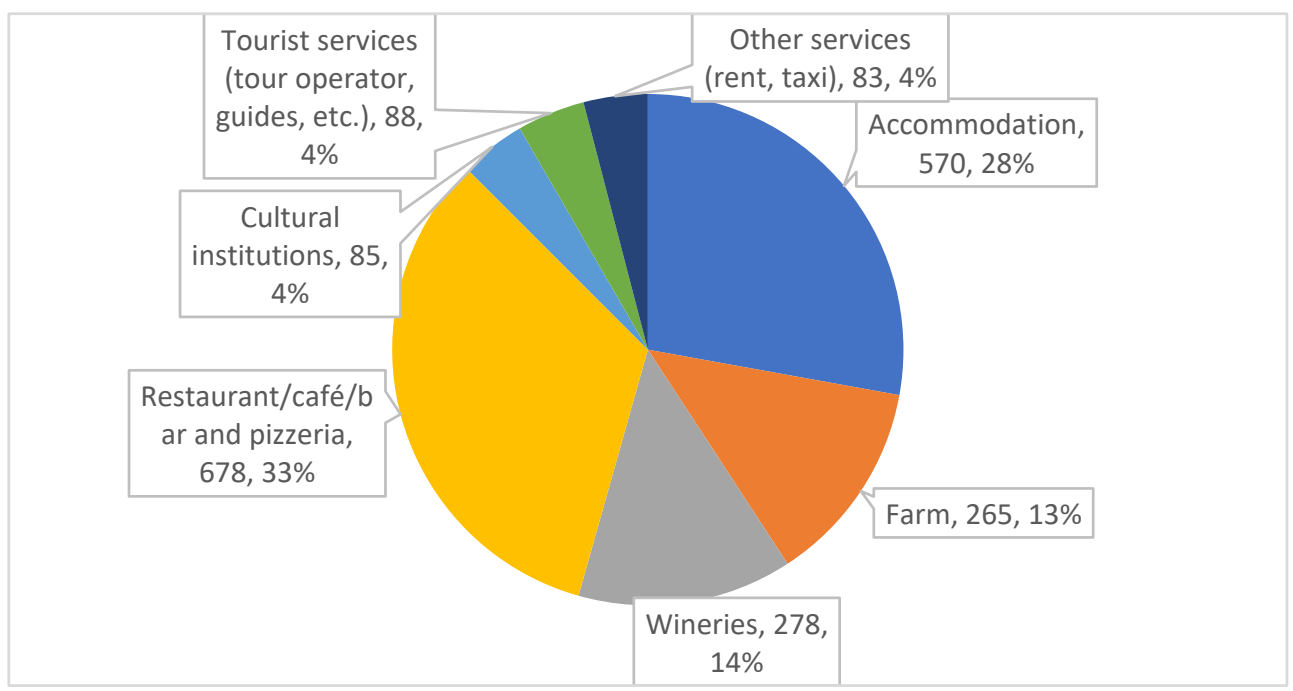

Figure 2. Composition of interviewed entrepreneurs and cultural bodies sample.

\subsection{Methods of Analysis}

In the international project, the surveys of the three target groups touched on diverse issues related to tourism, culture, and the coronavirus situation. In the project's questionnaires, a limited number of items were selected to answer the specific research questions in the Italian case study. This article describes the responses to questions concerning the interviewees' perceptions of cultural tourism, their understanding of tangible and intangible 
cultural heritage and its importance for the case study area as well as questions concerning the coronavirus situation.

Firstly, the research considered the nexus of culture and tourism in the residents' representations, looking at their definitions of cultural tourism and at which local cultural resources were freely named by interviewees. Those open-ended questions were examined through qualitative content analysis implemented through conceptual analysis. The coding method followed that described in the previous literature review as well as the definitions provided in the leading project. The text was pre-treated to remove articles and conjunctions. The absolute frequencies were calculated using Excel, and the results are described through their main occurrences. Word clouds enabled further description of the results, illustrating the semantic extensions of the answers; even if their scientific value is quite limited, these continue to be recognised as a simple and immediately apparent visualisation that captures perceptions at a glance.

The importance of cultural tourism assets and the perception of the coronavirus situation in all the interviewee groups, as expressed by Likert scales or close-ended questions, was analysed through descriptive univariate statistics (managed by SPSS software). The three samples were very different, and, for that reason, no more sophisticated statistical processes could be launched at this stage. On the one hand, both the local community's residents and entrepreneurs and cultural bodies were quite well represented, on the other, the scant number of tourist cases could not be considered in any statistical inference.

\section{Representations of Cultural Tourism}

\subsection{The Residents' Definition of Cultural Tourism}

The culture and tourism nexus in residents' representations were analysed: three open questions about the interviewees' definition of cultural tourism, what they see in their area of residence as the most interesting cultural assets and where they would accompany a guest (someone from outside). These three open questions showed what they considered valuable from a cultural point of view and their representation of the local cultural offer.

The interviewees represent (Figure 3) the idea of cultural tourism primarily as linked to museum experiences (83 occurrences), to history (89), to arts (81) and monuments (36), especially castles (23) and churches (23). The most recurrent actions associated with this experience are: visits and visiting (103), seeing (33), knowing (28), and discovering (9).

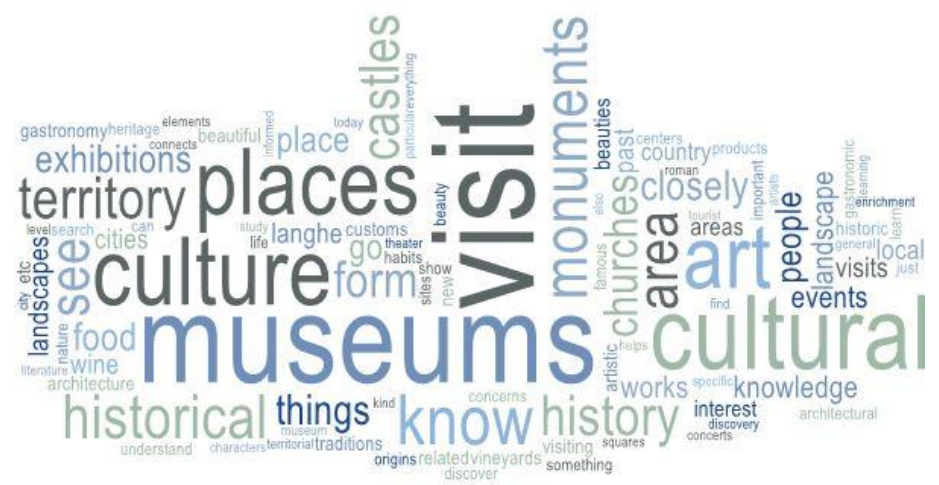

Figure 3. What is cultural tourism in your opinion? Word cloud from the open question (400 respondents).

Other rather widespread representations concern the idea of place (4 occurrences) and spots (26), notions of territory (45) and landscape (26). Beauty is a transversal theme named 22 times that intercepts both the characteristics of the visited heritage and aesthetic value, probably due to the specificity of the area concerned in terms of food and wine. Themes linked to recreation and leisure, such as holidays (3), entertainment (1) and diversion (1), were also detected. 
This picture highlights the association between the experience of cultural tourism and a passive experience of traditional, routinised and expressive practices and forms of tourism. An interesting theme arises here because, in a certain sense, it notes that the interviewees associate the experience of cultural tourism with a classic and all-encompassing idea of culture. Overall, according to their answers, the residents' approach cultural tourism positively (à la Tylor [56], to be clear), according to which culture (and the experiences associated with it) relates to civilization and the moral elevation of the spirit.

The residents' representations of cultural tourism show a typical dichotomy between heritage tourism and creative tourism: the past, settled in forms and practices of various kinds, associated with its experiential fruition. Both of these meanings seem to, in turn, presuppose a rather static representation of the tourist-cultural experience. In fact, if we try to split our reference binomial, we can associate a large part of the tourist experience with the idea of travel and visit, that is, a proactive action of the tourist towards an object that is in a different place than their habitual life. What is visited, seen, sightseen and known is a system of cultural objects [57] that reside and represent a fixed and immutable past.

\subsection{Importance of Attractions, Sites and Events in the Case Study Area}

\subsubsection{Residents' Perceptions}

In the group of residents, the importance of cultural attractions, sites and events in the case study area was doubly recorded. First, they were invited to freely indicate what they saw as cultural attractions, sites or events in their neighbourhood; second, they were asked to express, on a scale from 1 to 5 , the degree of importance of certain categories of sites and attractions as codified (see Table 1). This highlighted the specifics that the interviewees observed in the Langhe, Monferrato and Roero areas. The cultural attractions, sites and events that the interviewees freely named included the built cultural heritage, the local geography of cultural sites, the cultural motivations linked to local products and their transformation and, finally, the intangible cultural heritage of literature. Castles were the most frequently cited cultural attractions (67 occurrences), followed by museums (29), historical sites (23) and historical centres (12), arts and artistic attractions (26) and churches (20). According to residents, towers (7), monuments (6) and exhibitions (4) could be considered the secondary poles of cultural heritage attraction in the area (Figure 4).

Table 1. How important are the following cultural attractions/sites/events for this area on a scale of 1 (not important) to 5 (very important)?

\begin{tabular}{cc}
\hline Attractions/Sites/Events & Average Score \\
\hline Restaurants/food festivals & 4.48 \\
\hline Local traditions/folklore & 4.07 \\
\hline Historical sites and buildings & 4.02 \\
\hline Cultural heritage sites and buildings & 4.01 \\
\hline Cultural routes & 3.92 \\
\hline Townscapes & 3.87 \\
\hline Music events (concerts/festivals) & 3.59 \\
\hline Museums & 3.14 \\
\hline Religious sites/events & 3.05 \\
\hline (Film) theatre & 2.91 \\
\hline Sport events & 2.88 \\
\hline Art galleries & 2.74 \\
\hline Health sites (e.g., spas/hot springs) & 2.10 \\
\hline Dance events & 2.05 \\
\hline
\end{tabular}




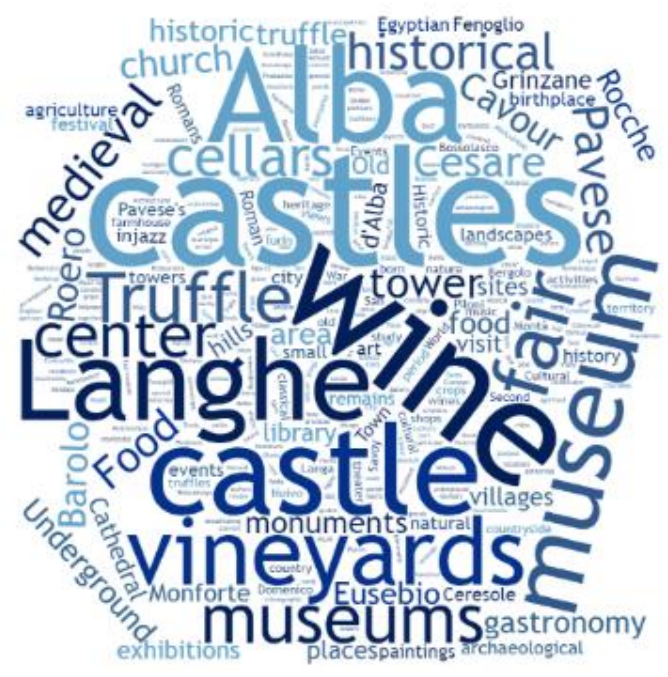

Figure 4. What do you see as cultural attractions, sites or events in this area? Word cloud from the open question (400 respondents).

If we focus on geographical attractions, the most named cultural site was the town of Alba (31 occurrences), but other places were also named, such as the Langhe (19), which, with Roero (6), is the topographical name of the case study area and covers the territorial integration area of Alba (selected for the sample). The other most frequently mentioned places were Barolo (6; although that is the name of a wine) and le Rocche (5), which is a picturesque chasm that is important in the history of the Resistance during the war. The landscape (15 occurrences) and hills (5) were the most cited comprehensive geographical terms, while vineyards (14) represent the connective element between the historical rural vocation of the territory and the visual appeal that visitors experience. In answers to the same open-ended question about the sites or cultural activities of greatest interest, specific traditional agricultural products were recognised in the truffle (18 occurrences) and its traditional fare (13), while the food and wine sector was named differently, with gastronomy (16) and culinary tradition, oeno-gastronomy (9), wine (12) and wine cellars (10).

Specific local intangible cultural heritage, such as literature, was named but definitely less prominent; Cesare Pavese (11 occurrences) and Beppe Fenoglio (4) were evoked by the interviewees, who also named the war (3) and the partisans (2) important in the biography, such as in the poetics of the writers mentioned above.

According to the residents, the most important cultural assets in the case study area are connected to gastronomy and wine. In fact, Alba was part of the UNESCO Creative Cities Network for Gastronomy since 2017 [58]. Piedmont food traditions are very important, particularly in its southern part, where the case study was focused. Traditionally connected to hazelnuts, the confectionery multinational Ferrero (brand of Nutella@) has its headquarters in Alba, while not far away, Carlo Petrini founded the international "Slow Food" movement in 1986.

Looking at activities with an average above 4 (on a scale of 1 to 5 ), the broad theme of local traditions, historical sites and cultural heritage emerges, which, further confirming what has been argued previously, note the importance that the interviewees attribute to the dimension of culture understood as a system of "classic" practices and expressions linked to spiritual cultivation.

This is followed by the sector that could be connected to the "territory": a system of resources and attractions related to the landscape, environment and places, namely the cultural itineraries and townscape. Finally, as can be seen, the vast majority of the dimensions proposed to the interviewees are above the median of 2.5 , testifying to the residents' opinion of having a remarkable cultural tourism offer in the area. 
The majority of interviewed residents consider an increase in cultural tourism in the area as highly positive for infrastructure, jobs, quality of life: the average score of the impact is 4.34. Moreover, despite that residents perceive the number of tourists as high or very high: it is on average 4.20 , but $55.25 \%$ of respondents choose the very positive impact on a Likert scale of five points. They do not feel annoyed by the tourists' presence in their daily life scoring the tourism-related nuisance on average at 2.06 . These three items suggest that the local community is aware of the importance of tourism for the area and has a positive opinion about their presence

\subsubsection{Tourists' Interests in the Case Study Area}

Tourists are the interviewees who can give the most significant information about the attractive factors of the area, despite the small number of interviews. First of all, it must be said that the composition of the sample of interviewees was almost exclusively made up of Italians (82.6\%) and local, continental tourists, especially Swiss (13.04\%). This composition naturally reflects the peculiar situation determined by COVID-19 in 2020.

Visitor motivations to travel to the Langhe area were mainly connected to restaurants and food, chosen by almost $74 \%$ of them. When interviewed about their cultural interests in visiting (Table 2), the food and wine sector records a very high average choice (4.88, on a scale of 1 to 5 ). It could be said that the main motivation that brings tourists to this area is restaurants, and gastronomy is also the only one. However, the choices related to other attractions should not be underestimated. If we consider only those that obtain a score higher than four, we can detect the strong identity expressed by the area (Table 2). In fact, classical cultural dimensions of the visited places have a preference for historical sites (4.31), cultural heritage sites (4.30), urban landscapes (4.29), cultural itineraries (4.23) and local traditions (4.04).

Table 2. How interested are you in visiting any of the following cultural attractions/sites/events on a scale of 1 (not interested at all) to 5 (very interested)?

\begin{tabular}{cc}
\hline Sites, Events and Attractions & Average Score \\
\hline Restaurants/food festivals & 4.88 \\
\hline Historical sites and buildings & 4.31 \\
\hline Cultural heritage sites and buildings & 4.30 \\
\hline Townscapes & 4.29 \\
\hline Cultural routes & 4.23 \\
\hline Local traditions/folklore & 4.04 \\
\hline Museums & 3.69 \\
\hline Music events (concerts/festivals) & 3.59 \\
\hline Religious sites/events & 2.85 \\
\hline Art galleries & 2.82 \\
\hline Health sites (e.g., spas/hot springs) & 2.77 \\
\hline Dance events & 2.43 \\
\hline (Film) theatre & 2.18 \\
\hline Sport events & 2.13 \\
\hline
\end{tabular}

\subsubsection{Entrepreneurs and Cultural Bodies' Cultural Tourism Offer}

Entrepreneurs and cultural bodies were interviewed regarding their main offer and what they would further develop in the case study area. Gastronomy and wine-related tourism is the main lever of tourism in the case study area $(81 \%$; Table 3$)$. This is followed by heritage and folklore with local traditions. Such a configuration certainly shows the two main attractors of the area but equally demonstrates interest in supporting and developing 
other sectors. For example, when the interviewees chose the "other" category, they mentioned outdoor activities and related themes such as sports and open-air tours or rambling several times.

Table 3. What cultural themes does your business offer? Please indicate for each of the following themes whether your business offers it, and choose which one is the most important.

\begin{tabular}{ccc}
\hline Cultural Themes & Percentage Respondents & the Most Important \\
\hline Gastronomy/Wine & $81.40 \%$ & $42.33 \%$ \\
\hline Heritage & $52.56 \%$ & $18.14 \%$ \\
\hline $\begin{array}{c}\text { Folklore/local traditions } \\
\text { (including festivals) }\end{array}$ & $26.98 \%$ & $14.88 \%$ \\
\hline Architecture/townscapes & $18.14 \%$ & $0.47 \%$ \\
\hline History & $16.74 \%$ & $7.91 \%$ \\
\hline Artwork & $8.84 \%$ & $6.51 \%$ \\
\hline Other & $8.37 \%$ & 0 \\
\hline Literature & $4.19 \%$ & $0.93 \%$ \\
\hline Archaeology & $4.19 \%$ & 0 \\
\hline Music & $1.86 \%$ & $0.47 \%$ \\
\hline Religion & $1.86 \%$ & $1.40 \%$ \\
\hline Film & $0.93 \%$ & 0 \\
\hline Theatre & $0.93 \%$ & 0 \\
\hline Dance & $0.00 \%$ & 0 \\
\hline
\end{tabular}

The entrepreneurs and cultural bodies were asked to agree/disagree with ten statements about cultural tourism in the area. This question sought to understand the relations among cultural tourism, cultural assets and tourism governance (Table 4).

Table 4. Please indicate your agreement with any of the following statements regarding cultural tourism in your area, on a scale from 1 (strongly disagree) to 5 (strongly agree).

\section{Statements about Cultural Tourism in the Area}

It is important that cultural tourism is present in this area

There are still locations/traditions in this area that have the potential to become a cultural attraction/site/event

This area has a lot of potential for cultural tourism, i.e., it has a strong cultural appeal

Government should invest in the development of cultural tourism in this area

Government should help businesses with developing and increasing cultural tourism in this area

\begin{tabular}{cl}
\hline Tourist numbers should be higher in this area & 3.48 \\
\hline Tourist flows should be better regulated in this area & 3.46 \\
\hline There are enough cultural attractions/sites/events in this area & 3.19 \\
\hline There is a good diversity of cultural attractions/sites/events in this area & 3.16 \\
\hline There are enough cultural attractions/sites/events in this area & 3.07 \\
\hline
\end{tabular}

\section{Average Entrepreneurs and Cultural Bodies}

3.64

$$
3.64
$$

3.57

3.52

64

\section{8}


In summary, the respondents consider the presence of cultural tourism in the area very important (3.64), and the area has a lot of potential with appealing locations and traditions, while the government should firstly invest in developing cultural tourism in the area then secondarily helping businesses.

When interviewed about the cultural themes they would like to see further developed, the wine and food sector stands out: $50.5 \%$ of respondents would like to see it further developed, followed by natural and cultural heritage (30.5\%), folkloric and traditional forms of expression (15.9\%), literary heritage (10.4\%) and historical heritage (9.7\%). This also explains the perception of the territory's strong tourism-cultural potential among business operators, which records an average of 3.58 .

According to the interviewees, there are still some difficulties in the management and regulation of tourist flows (average 3.46) and in the general development of cultural tourism in the area (3.07). This must all be considered within the context of the operators' uniform satisfaction, at least in an ordinary context and not that affected by the emergency conditions due to the pandemic. The aspects for potential improvement of the tourism offer in the area and which could, according to the interviewees, strengthen the economic income in the area, are above all the organisation of a greater number of events (which $29.6 \%$ of the interviewees declared as the first to be strengthened), followed by the ability to better guide tourists by providing visitors with information (23.4\%), and lastly, the growth of available attractions, understood in the sense of enjoyable experiences $(18.5 \%)$.

\section{Perceptions of the Coronavirus Crisis: Impacts on Cultural Tourism}

The pandemic has profoundly changed almost every aspect of social and individual life. If any sector has been especially affected, it is certainly that of hospitality and the travel industry. When the pandemic was declared in March 2020, Italian tourist flows were expanding compared to the same period of 2019. According to Italian statistics, tourist arrivals and presences decreased in Italy by $82.4 \%$ in March 2020 and $95.4 \%$ in April 2020 [59]. The summer period of 2020 represents a stall in the decrease for some sea and mountain destinations. According to the Regional Tourist Observatory, tourist movements in the case study area throughout 2020 registered a decrease of 51\% in overnight stays compared to 2019 [60].

\subsection{Residents and COVID-19}

The residents were asked how the coronavirus pandemic has impacted their fruition of cultural assets. In order to compare the three different targets, the same categories of attractions, sites and events were kept. We asked the interviewees how much the COVID-19 epidemic has affected their possibility of travelling long distances. Thus, they were asked if, since March 2020, they had visited cultural sites and participated in cultural activities in their surroundings more than before the coronavirus crisis or less than before (Table 5).

As expected, the spread of the COVID-19 epidemic has heavily influenced the possibility of access and use of almost all the cultural tourism attractions in the area, affecting indoor activities above all, which were closed to the public for a long time. The only attraction that has resisted concerns the urban landscape, which, on a scale from 1 (I visit much less) to 5 (I visit much more), records a score equal to 2.21. This is followed by religious rites (1.98), to which, however, we can probably ascribe a non-strict tourist function and more of a ritual one. Finally, the restaurant and food sector "holds" 1.98, further confirming the marked specificity of the case study area. These are certainly preliminary results that are strongly affected by the economic situation of the year 2020, which, in Italy, was characterised by many weeks (March-April) of total lockdown of each activity. There was a limited recovery in spring and summer and a new lockdown, albeit softer, starting from the beginning of autumn, the season in which the Langhe, Monferrato and Roero concentrate most of the tourist activities. 
Table 5. Do you currently (since the crisis began in March 2020) visit cultural sites and participate in cultural activities in your own surroundings more than before the crisis on a scale from 1 (I visit much less) to 5 (I visit much more) with 3 being neutral (I visit the same as before)?

\begin{tabular}{cc}
\hline Attractions/Sites/Events & Average Residents \\
\hline Townscapes & 2.21 \\
\hline Religious sites/events & 1.98 \\
\hline Restaurants/food festivals & 1.98 \\
\hline Historical sites and buildings & 1.96 \\
\hline Cultural heritage sites and buildings & 1.96 \\
\hline Cultural routes & 1.93 \\
\hline Sport events & 1.79 \\
\hline Museums & 1.76 \\
\hline Local traditions/folklore & 1.73 \\
\hline Art galleries & 1.73 \\
\hline Music events (concerts/festivals) & 1.70 \\
\hline (Film) theatre & 1.65 \\
\hline Health sites (e.g., spas/hot springs) & 1.65 \\
\hline Dance events & 1.64 \\
\hline
\end{tabular}

\subsection{Tourists and COVID-19}

The consequences of the COVID-19 epidemic on the tourist experience have obviously had a significant impact. On a scale of 1 (very little) to 5 (very much), the epidemic has changed the respondents' way of travelling by an average of 4.02. The tourists express a general sense of reduction: less travel, fewer stops during the journey, fewer holidays, less overnight stays. In terms of how the interviewees declared having changed their way of travelling after the pandemic was declared, this was not only by reducing their travel, but also changing destinations (necessarily choosing "domestic" destinations) and, above all, paying greater attention to hygiene and health rules in relation to social distancing and personal protection. In fact, they avoid travel abroad, and the destinations are restricted to those nearby, also restricting the travel group to the family: about one-third of them came from the adjacent Italian region Lombardy. Other cautions are also named, reporting the necessity of avoiding public transport. Some respondents also expressed emotions connected to the actual pandemic situation, such as fear, anxiety and feeling and suffering limitations on their freedom. Finally, a significant number of respondents declared having a certain impatience with these rules (from the obligation to wear a mask to access quotas).

The health restrictions imposed, obviously indispensable, limit first of all the possibility of experience, understood in the sense of escape from everyday life, which is the very and most profound essence of tourism. When the interviews were collected in autumn 2020, Italy was emerging from a summer season of relative domestic tourism recovery before the second wave of COVID-19. The case study area of Langhe Monferrato and Roero is a weekend destination. Even if it is still an unrefined statistic, one of the issues produced by the pandemic event appears to use here, which generally impacts and will have the greatest impact on the tourism sector.

\subsection{Entrepreneurs and Cultural Bodies' Perception of COVID-19}

The pandemic strongly affected tourism-related activities in the area: $97.8 \%$ of the respondents were affected and were interviewed on how their business has been affected by the coronavirus pandemic (Table 6). 
Table 6. In what ways has your business been affected by the coronavirus pandemic on a scale from 1 (no impact) to 5 (strong impact)?

\begin{tabular}{cc}
\hline & Average Entrepreneurs and Cultural Bodies \\
\hline Reduced international visitor numbers & 4.42 \\
\hline Cancelled events & 4.28 \\
\hline Booking cancellations & 4.24 \\
\hline Reduced bookings & 4.15 \\
\hline Rearrangements/postponement of bookings & 3.94 \\
\hline Forced closure of your establishment & 3.84 \\
\hline Reduced national visitor numbers & 3.58 \\
\hline
\end{tabular}

The greatest impact was felt in relation to the reduction in the number of international tourists (4.42), followed by the cancellation of organised events (4.28) and reservations (4.24). A relatively smaller reduction was declared in the number of domestic tourists. The entrepreneurs and cultural bodies facing the emergency revealed a significant datum in autumn 2020: a significant resilience of the area's economic system. Almost all of the respondents declared that they have not been able to recruit new staff during the year $(96 \%)$; more than half $(54.8 \%)$ benefited from social safety nets such as wage support $(54.8 \%) ; 33.6 \%$ retained the staff employed in their workforce even if at zero activity, while $23.4 \%$ opted for the use of partial leave such as forced holidays. The fact that the impact of the pandemic is dramatic, but nevertheless allows us to glimpse some light, is also shown by the data relating to the resilience of operators in the current conditions: $27.9 \%$ of the companies in extremely serious difficulty were, however, able to resist at most three months. This is almost one in three and is a figure that requires articulate reflections. Those with medium difficulty (successfully resisting between six and nine months) were $32.21 \%$, while those who claim to have enough oxygen for a year or more represent $39.9 \%$ of the sample. In other words, the resistance time horizon of six out of ten operators is less than one year (in semi-lockdown conditions), while four out of ten seem to have more breath.

\section{Discussion and Conclusions}

This article described social representations and perceptions of cultural tourism in a case study from multiple points of view, including those of residents, tourists and local entrepreneurs and cultural bodies in the time of the coronavirus. In the residents' sample, those representations and perceptions were examined mainly from a qualitative point of view. The open-ended questions posed at the beginning of the questionnaire provided an understanding of what the respondents spontaneously meant by the expression of cultural tourism and identified the main cultural attractions, sites and events that they considered important in their area. The content analysis highlighted a definition of cultural tourism linked primarily to what is traditionally attributed to high culture and that generally embraces the fruits of the culturally built heritage. Museums, history, the arts and monuments (especially as exemplified in castles and churches) were perceived as national cultural heritage, as was their preservation and transmission from one generation to the next.

Looking at what kind of experiences were regarded as cultural tourism, quite passive experiences of routine practices were mostly suggested; among the most cited, visiting, seeing, and knowing are all activities that harken back to traditional, institutionalised forms of tourism. Similarly, looking at the sites or attractions freely evoked, the choices were mainly of the historical and built heritage, with an almost equal recognition of the importance of local agricultural products and the wine-related tradition. In this sense, this research did not explicitly find the well-known turn to the experience economy, which also involves cultural tourism practices, as conceptualised by Andersson [26], detected by Richards [23] and variously welcomed or ascertained by Italian scholars, such as Di Trapani [44] and Becheri et al. [45]. 
By comparing the three samples' respective perceptions of cultural tourism, the case study highlights that residents have a static representation of cultural tourism, even if they recognise the specific appeal of their area through references to events, the landscape and local rural cultural resources. This is in line with the most common definitions established in Italy, but it does not represent all the richness of current trends in cultural tourism as actually experienced by the 21st-century tourist. Food and wine were both the main tourist motivations and the most important cultural tourism themes offered as recognised by both tourists and the local entrepreneurs and cultural bodies interviewed. This confirms that, in the case study area, tourist practices have moved towards experiences and a more creative way of visiting and promoting places.

The research results underline the destination's double vocation and its uncertain compatibility. The town of Alba is the main centre that ISTAT [61] has classified, as a municipality, in the cultural, historical, artistic and landscape vocation as established on the basis of the tourist density index. The surrounding area included in the case study expresses a more complex vocation; hills, landscapes and historic villages, with their rural past and present (holiday farms are numerous), do not have a comprehensive and exclusive classification. On the basis of its local distinctiveness [24], the area has pursued the aims of international recognition and local-global identification. The UNESCO inscriptions in the World Heritage List and in the UNESCO Creative Cities Network offer a precise mechanism whereby global standards are interpreted in a framework for the co-production of heritage and tourism. From a theoretical point of view, cultural resources may be interpreted holistically; tangible and intangible cultural heritage are interconnected, but, ultimately, when a destination is promoted on the market, it must be associated with a recognisable heritage, at least at the regional level [62]. In the case study area, the collected data did not allow for making larger assumptions on the specific matters of cultural change caused by the specific tourism levers represented by the food and wine sectors.

In autumn 2020, when data were collected, Coronavirus crisis perception was serious for all the three interviewed targets but not tragic yet. Both residents and tourists do manifest a wide decrease of any kind of cultural activity, and this is also caused by the reduction in supply and in the effective possibility to participate because of Coronavirusrelated rules. When asked to look to the near future, the entrepreneurs and cultural bodies project their durability in the year 2021. At present, we are not sure this estimation is still valid. However, local community and tourism stakeholders have continued to work towards a destination recovery and relaunch.

Author Contributions: Conceptualization, G.R. and L.M.; methodology, L.M.; formal analysis, G.R. and L.M.; investigation, G.R. and L.M.; data curation, G.R. and L.M.; writing-original draft preparation, G.R. (Sections 1-4 and 6) and L.M. (Sections 3-5); visualization, G.R.; supervision, L.M.; project administration, L.M.; funding acquisition, L.M. Both authors have read and agreed to the published version of the manuscript.

Funding: This article comprises the results of the project "Project Social and Innovative Platform on Cultural Tourism and its potential towards deepening Europeanisation" (SPOT). This project has received funding from the European Union's Horizon 2020 research and innovation programme under grant agreement No 870644. The article reflects only the author's view and the Research Executive Agency is not responsible for any use that may be made of the information it contains.

Institutional Review Board Statement: The study was conducted according to the guidelines of the Declaration of Helsinki, and approved by the Ethics Committee of Mendelova Univerzita v Brnĕ (protocol code 13, 08.10.2020).

Informed Consent Statement: All data were collected anonymously and neither the researchers nor anyone else is able to identify individual participants who agreed to answer the questionnaires.

Data Availability Statement: Not applicable.

Conflicts of Interest: The authors declare no conflict of interest. 


\section{References}

1. Impresa Cultura, Comunità, Territori, Sviluppo. XIV Rapporto Annuale Federculture; Gangemi Editore: Roma, Italy, 2018.

2. Vespignani, F.; Farneti, E. 'Il Museo Italia. Siamo Primi al Mondo per Patrimonio ma Sappiamo Valorizzarlo?/I'. Blog Il Fatto Quotidiano, 17 Giugno 2018. 2018. Available online: https:/ /www.ilfattoquotidiano.it/2018/06/17/il-museo-italia-siamo-primial-mondo-per-patrimonio-ma-sappiamo-valorizzarlo-i/4427096/ (accessed on 17 February 2021).

3. Giannini, F. 'La Favola dell'Italia Che ha il “50\% del Patrimonio Artistico Mondiale”', Finestre Sull'arte, 04/05/2012. 2012. Available online: https://www.finestresullarte.info/3n_favola-dell-italia--50-per-cento-del-patrimonio-artistico-mondiale.php (accessed on 17 April 2019).

4. The Best Countries Ranking of the US News \& World Report. Available online: https://www.usnews.com/news/best-countries / influence-rankings (accessed on 28 April 2021).

5. Morvillo, A.; Becheri, E. (Eds.) Dalla Crisi alle Opportunità per il Futuro del Turismo in Italia. Supplemento alla XXIII Edizione del Rapporto sul Turismo Italiano; Rogiosi: Napoli, Italy, 2020.

6. World Heritage List Inscribed Property of Vineyard Landscape of Piedmont: Langhe-Roero and Monferrato. Available online: https://whc.unesco.org/en/list/1390/ (accessed on 28 April 2021).

7. Ercole, E. Il turismo Rurale Nelle Colline Piemontesi. In Scenari e Tendenze Della Mobilità Turistica; Romita, T., Catalano, G., Perri, A., Eds.; Aracne: Roma, Italy, 2015; pp. 157-173.

8. Ercole, E. Turismo Rurale. Sviluppo Locale, Sostenibilità, Autenticità, Emozioni; FrancoAngeli: Milano, Italy, 2019.

9. Santagata, W.; Trimarchi, M. Turismo Culturale e Crescita del Territorio. Identità Tradizioni e Piaceri nel Monferrato; FrancoAngeli: Milano, Italy, 2007.

10. Landscape and Literary Park. Available online: http://www.parcoletterario.it/index.php (accessed on 28 April 2021).

11. Murphy, P. Tourism: A Community Approach; Methuen: London, UK, 1985.

12. Bramwell, B. Local Participation in Community Tourism: A Critical and Relational Assessment. In The Wiley Blackwell Companion to Tourism; Lew, A.A., Hall, C.M., Williams, A.M., Eds.; John Wiley \& Sons: Hoboken, NJ, USA; Chichester, UK, 2014 ; pp. 556-566.

13. Lankford, S.V. Attitudes and perceptions toward tourism and rural regional development. J. Travel Res. 1994, 32, 35-43. [CrossRef]

14. Ap, J. Residents' perceptions on tourism impacts. Ann. Tour. Res. 1992, 19, 665-690. [CrossRef]

15. Andereck, K.L.; Valentine, K.M.; Knopf, R.C.; Vogt, C.A. Residents' perceptions of community tourism impacts. Ann. Tour. Res. 2005, 32, 1056-1076. [CrossRef]

16. Besculides, A.; Lee, M.E.; McCormick, P.J. Residents' perceptions of the cultural benefits of tourism. Ann. Tour. Res. 2002, 29, 303-319. [CrossRef]

17. Bello, F.G.; Carr, N.; Lovelock, B.; Xu, F. Local residents' perceptions of socio-cultural impacts of tourism in Mangochi, Malawi. Adv. Hosp. Tour. Res. 2017, 5, 1-22.

18. Moscardo, G. Tourism and Sustainability: Challenges, Conflicts and Core Knowledge. In Education for Sustainability in Tourism. A Handbook of Processes, Resources, and Strategies; Moscardo, G., Benckendorff, P., Eds.; Springer: Berlin/Heidelberg, Germany, 2015; pp. 25-43.

19. Larson, L.R.; Poudyal, N.C. Developing sustainable tourism through adaptive resource management: A case study of Machu Picchu, Peru. J. Sustain. Tour. 2012, 20, 917-938. [CrossRef]

20. Loulanski, T.; Loulanski, V. The sustainable integration of cultural heritage and tourism: A meta-study. J. Sustain. Tour. 2011, 19, 837-862. [CrossRef]

21. Zolfani, S.H.; Sedaghat, M.; Maknoon, R.; Zavadskas, E.K. Sustainable tourism: A comprehensive literature review on frameworks and applications. Econ. Res. Ekon. Istraživanja 2015, 28, 1-30. [CrossRef]

22. Leed, E.J. The Mind of the Traveler: From Gilgamesh to Global Tourism; Basic Books: New York, NY, USA, 1991.

23. Richards, G. Cultural tourism: A review of recent research and trends. J. Hosp. Tour. Manag. 2018, 36, 12-21. [CrossRef]

24. Salazar, N.B. The Glocalisation of Heritage through Tourism. Balancing Standardization and Differentiation. In Heritage and Globalisation; Labadi, S., Long, C., Eds.; Routledge: London, UK, 2010; pp. 130-146.

25. Holden, A. Tourism Studies and the Social Sciences; Routledge: London, UK, 2005.

26. Andersson, T.D. The Tourist in the Experience Economy. Scand. J. Hosp. Tour. 2007, 7, 46-58. [CrossRef]

27. Terkenli, T.S. Landscapes of Tourism. In The Wiley-Blackwell Companion to Tourism, 1st ed.; Lew, A.A., Hall, C.M., Williams, A.M., Eds.; John Wiley \& Sons, Ltd.: New York, NY, USA, 2014; pp. 282-293.

28. Daugstad, K. Negotiating landscape in rural tourism. Ann. Tour. Res. 2008, 35, 402-426. [CrossRef]

29. Corvo, P. Food Culture, Consumption, and Society; Palgrave: London, UK, 2015.

30. Dixit, S.K. The Routledge Handbook of Gastronomic Tourism, 1st ed.; Routledge: London, UK, 2021. [CrossRef]

31. Du Cros, H.; McKercher, B. Cultural Tourism, 3rd ed.; Routledge: London, UK, 2020.

32. Tourism and Culture Synergies. Available online: https://www.e-unwto.org/doi/book/10.18111/9789284418978 (accessed on 1 June 2021).

33. MacLeod, N. Cultural Tourism: Aspects of Authenticity and Commodification. In Cultural Tourism in a Changing World: Politics, Participation and (Re)presentation; Smith, M.K., Robinson, M., Eds.; Channel: Clevedon, UK, 2006; pp. 177-190.

34. Bargeman, B.; Richards, G. A new approach to understanding tourism practices. Ann. Tour. Res. 2020, 84, 102988. [CrossRef] [PubMed] 
35. Holtorf, C. 'Cultural Heritage Is Concerned with the Future': A Critical Epilogue. In Critical Perspectives on Cultural Memory and Heritage. Construction, Transformation and Destruction; Apaydin, V., Ed.; UCL Press: London, UK, 2020; pp. $309-311$.

36. Smith, L. Uses of Heritage; Routledge: London, UK, 2009.

37. Cousin, S. L'Unesco et la doctrine du tourisme culturel. Civilisations 2008, 57. [CrossRef]

38. Palumbo, B. L'Unesco e il Campanile: Antropologia, Politica e Beni Culturali in Sicilia Orientale; Meltemi: Roma, Italy, 2003.

39. De Seta, C. L'Italia Nello Specchio del Grand Tour; Rizzoli: Milano, Italy, 2014.

40. Chaney, E. The Evolution of the Grand Tour: Anglo-Italian Cultural Relations Since the Renaissance; Routledge: London, UK; New York, NY, USA, 2014.

41. Emiliani, A. Il patrimonio artistico e storico prima dell'unificazione italiana. Econ. Della Cult. 2011, 21, 357-369. [CrossRef]

42. van der Borg, J.; Costa, N. Cultural Tourism in Italy. In Cultural Tourism in Europe; Richards, G., Ed.; CAB: Wallingford, UK, 1996; pp. 156-169.

43. Dattilo, B.; Gitton, F.; Khiati, A.; Sabato, M. Analysing Cultural Tourism in France and Italy. In Proceedings of the 14th Global Forum on Tourism Statistics, Venice, Italy, 23-25 November 2016.

44. Di Trapani, G. Dal Turismo Culturale al Turismo Esperienziale e Creativo. In Rapporto Sul Turismo Italiano 2008-2009; Becheri, E., Ed.; FrancoAngeli: Milano, Italy, 2009; pp. 609-626.

45. Becheri, E.; Micera, R.; Morvillo, A. Introduzione. In Rapporto Sul Turismo Italiano, XXII Edizione 2017-2018; Becheri, E., Micera, R., Morvillo, A., Eds.; Rogiosi: Napoli, Italy, 2018; pp. 23-27.

46. Montaguti, F.; Meneghello, S. L'ascesa del Turismo del Paesaggio Culturale. In Rapporto Sul Turismo Italiano XXI Edizione; Becheri, E., Micera, R., Morvillo, A., Eds.; Rogiosi: Napoli, Italy, 2017; pp. 665-676.

47. Ercole, E.; Gilli, M. Il Turismo Come Fattore di Sviluppo Locale Nelle Aree Rurali: Studio del Caso Astigiano. In Turismo, Territorio, Identità; Savelli, A., Ed.; FrancoAngeli: Milano, Italy, 2004; pp. 79-108.

48. Haywood, K.M. A post COVID-19 future-Tourism re-imagined and re-enabled. Tour. Geogr. 2020, 22, 599-609. [CrossRef]

49. Uzuner, G.; Ghosh, S. Do pandemics have an asymmetric effect on tourism in Italy? Qual. Quant. 2020, 1. [CrossRef] [PubMed]

50. Găitan, I.-D. Managing the Coronavirus pandemic impact on tourism in Spain, Italy, Romania and Poland. SEA Pract. Appl. Sci. 2020, 23, 227-233.

51. Sanfelici, M. The Italian Response to the COVID-19 Crisis: Lessons Learned and Future Direction in Social Development. Int. J. Community Soc. Dev. 2020, 2, 191-210. [CrossRef]

52. Pasquinelli, C.; Trunfio, M.; Bellini, N.; Rossi, S. Sustainability in Overtouristified Cities? A Social Media Insight into Italian Branding Responses to Covid-19 Crisis. Sustainability 2021, 13, 1848. [CrossRef]

53. Regional Territorial Plan of Piedmont. Available online: www.regione.piemonte.it (accessed on 7 July 2020).

54. Istituto Nazionale di Statistica. Available online: http:/ / demo.istat.it/index_e.php (accessed on 7 July 2020).

55. International White Truffle Fair in Alba. Available online: https://www.fieradeltartufo.org/en/ (accessed on 20 February 2021).

56. Tylor, E.B. Primitive Culture. Researches into the Development of Mythology, Philosophy, Religion, Art, and Custom; Gordian Press: New York, USA, 1974.

57. Griswold, W. Cultures and Societies in a Changing World; SAGE: London, UK, 2013.

58. UNESCO Creative Cities Network as Creative City of Gastronomy. Available online: https://en.unesco.org/creative-cities/alba (accessed on 29 April 2021).

59. Istituto Nazionale di Statistica. Movimento Turistico in Italia. Primi Nove Mesi Del 2020: Presenze Dimezzate Negli Esercizi Ricettivi. Roma, 29 Dicembre 2020. Available online: https://www.istat.it/it/archivio/252091 (accessed on 17 February 2021).

60. Regional Tourist Observatory. Available online: https://www.visitpiemonte-dmo.org/osservatorioturistico/ (accessed on 17 February 2021).

61. Istituto Nazionale di Statistica. Classificazione dei Comuni in Base Alla Densità Turistica. Roma, 17 Settembre 2020. Available online: https:/ / www.istat.it/it/archivio/247191 (accessed on 21 May 2021).

62. Piva, E.; Prats, L. Regional Destination and Brand Identity: The Case of Piedmont, Italy. Sci. Reg. 2021, 1, 83-105. [CrossRef] 